\title{
TECHNICAL MONITORING SYSTEM FOR A NEW PART OF GDAŃSK DEEPWATER CONTAINER TERMINAL
}

\author{
Mikołaj Miśkiewicz ${ }^{1}$ \\ Łukasz Pyrzowski ${ }^{1}$ \\ Krzysztof Wilde ${ }^{1}$ \\ Oskar Mitrosz ${ }^{2}$ \\ ${ }^{1}$ Gdansk University of Technology, Poland \\ ${ }^{2}$ Keller Polska Sp. z o.o., Poland
}

\begin{abstract}
Development strategy for the port of Gdan'sk assumes that, up to 2027, it will become the main transport centre in the Baltic Sea region. To this end, for many years work has been carried out to facilitate access to the port both by sea and land. One of the elements of extension of the port is the building of another terminal of Deepwater Container Terminal, Gdańsk. In this task, geotechnical operations aimed at appropriate preparation of subgrade for storage of containers and operation of cranes, have been especially important. Effectiveness of the assumed design solution of land-side girder for gantry crane has been verified by means of a technical monitoring system. This paper presents main elements of design the land-side girder of a new quay of the container terminal in Gdańsk, together with its computational analysis, as well as the results collected during a few months of observation, which have revealed real work of monitored elements.
\end{abstract}

Keywords: SHM, monitoring, DCT of Gdańsk, geotechnics

\section{INTRODUCTION}

Development strategy for Gdansk port assumes that it will become, up to 2027, the main transport centre in the Baltic Sea region [3]. The main element which shows importance of the port is its location as well as the fact that the East Europe region is the most dynamically developing part of Europe. For many years investments have been carried out in order to facilitate access to the port both by sea and from land. One of the elements of the approved strategy is the extension of the Deepwater Container Terminal in Gdańsk, which has been aimed at the building of a terminal for servicing container carriers of ULCV class (Ultra Large Container Vessels) of over 18,000 TEU (Twenty-foot Equivalent Units) capacity (Fig. 1), that required deepening the basin and performing appropriate diagnostics [6], [7], [13], [20]. In this task, in view of a complex soil - water conditions, all geotechnical operations constituted a crucial element for successful finalization of the undertaking. They were aimed at appropriate preparation of the subgrade over 25 ha area for ship mooring berths, operation of cranes and storage of containers. The contract area has been divided into two main parts [14]: heavy foundation for girder of STS (Ship-toshore) gantry crane as well as the deep soilimprovement of the platform (storage area for containers) and the quay wall (45m far into land from crane sea-side rail). 


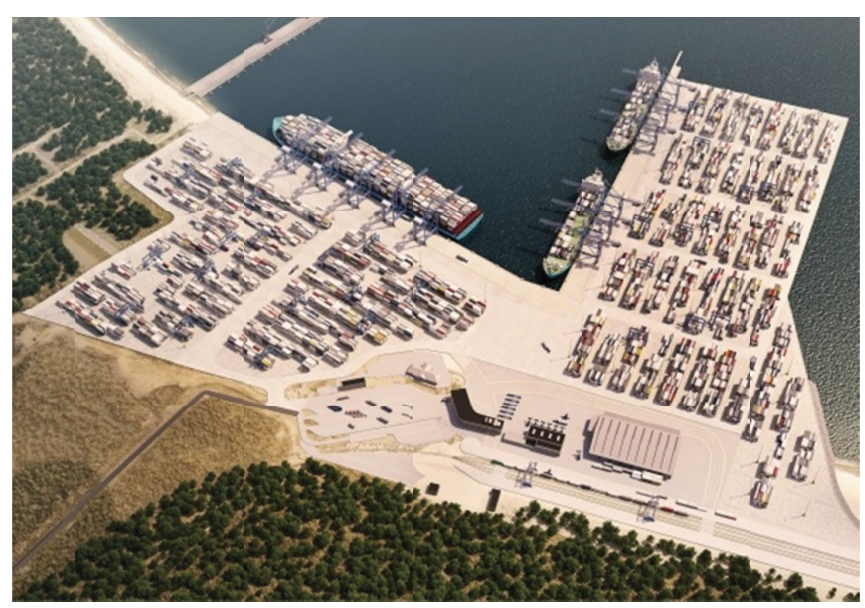

Fig. 1. Bird view of new ship mooring berths and containers storage areas (acc. DCT Gdańsk S.A.)

For the reason of a complex character of operations within the quay it was decided to verify the accepted design solution of land-side girder foundation (Keller Polska Ltd. Co) by applying a technical monitoring system installed on steel rods of micro-piles (Gdańsk University of Technology).

\section{CHARACTERISTICS OF THE MONITORED STRUCTURE}

The land-side girder within which the monitored rods were placed, was designed as a pile capping beam supported onto a wall combined with pipes and steel profiles anchored by means of pair of tie-rods in the rear (land-side) crane girder which was founded on CFA piles arranged in racking trestle system (Fig. 2) [3]. Additionally, the land-side girder was anchored with the use of micro-piles of $300 \mathrm{~mm}$ diameter, inclined by $45^{\circ}$, and having the length from 31 up to $36 \mathrm{~m}$. The system rods made of $28 \mathrm{Mn} 6$ steel constituted the steel element of micro-piles. Cyclic monitoring was applied to axial forces acting in 7 (out of 290 produced) micro-piles placed over the whole length of the quay (Fig. 3).

The micro-piles were made of high quality steel pipes whose elements of 1 up to $4 \mathrm{~m}$ in length were joined by means of couplers. Owing to application of a drill bit, $300 \mathrm{~mm}$ diameter was obtained along the whole length of micro-pile. The reinforcement pipe served as a drilling and injection duct. The drilling down the pipe was performed under protection of drilling fluid and in case an obstacle was met the operation was supported by impact. When the rod was drilled down up to the designed depth the second phase of injection of elevated density cement grout followed. The application of

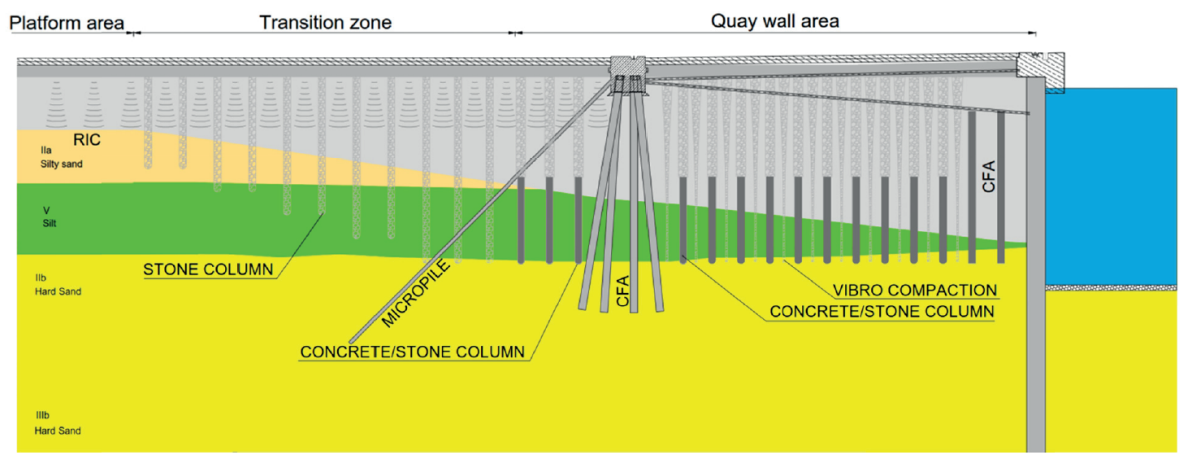

Fig. 2. Cross-section of the quay

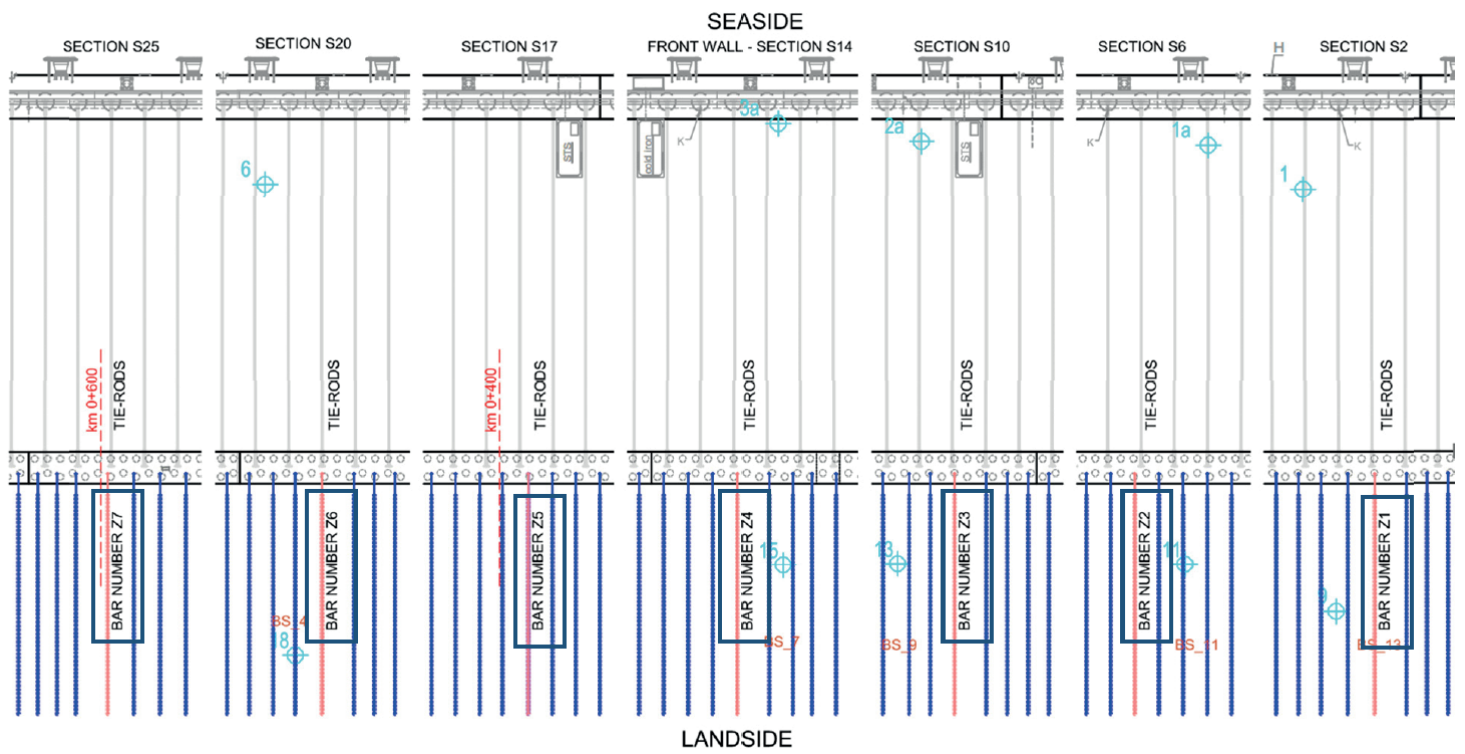

Fig. 3. Top view of the quay, showing location of the monitored micro-piles 
the self-drilled system micro-piles is simple to perform as the drilling and injecting operations occur simultaneously, and the drill rod is also used as a final reinforcement without need of using any protection pipes. Moreover, the irregular- fuzzed shape of injection body produces excellent connection with the ground, which results in a high load-carrying ability of micro-pile and displacements necessary to activate friction on side surface amount to only a few millimeters.

\section{DESIGN PROCESS AND LOAD TEST}

Computational simulations of behaviour of the structure was performed in linear elastic range as well as non-linear one by using the finite elements method [4], [5]. In the context of applicability of the FEM a formal analysis of the solution convergence was made. Two independent FEM models were prepared in order to highlight work of the gantry crane girder and foundation elements as well (Fig. 4). The first of them represented global behaviour of the designed structure with taking into account sea actions, and the other was directed to proper description of the land-side support, i.e. behaviour of the pile trestle and micro-piles system.
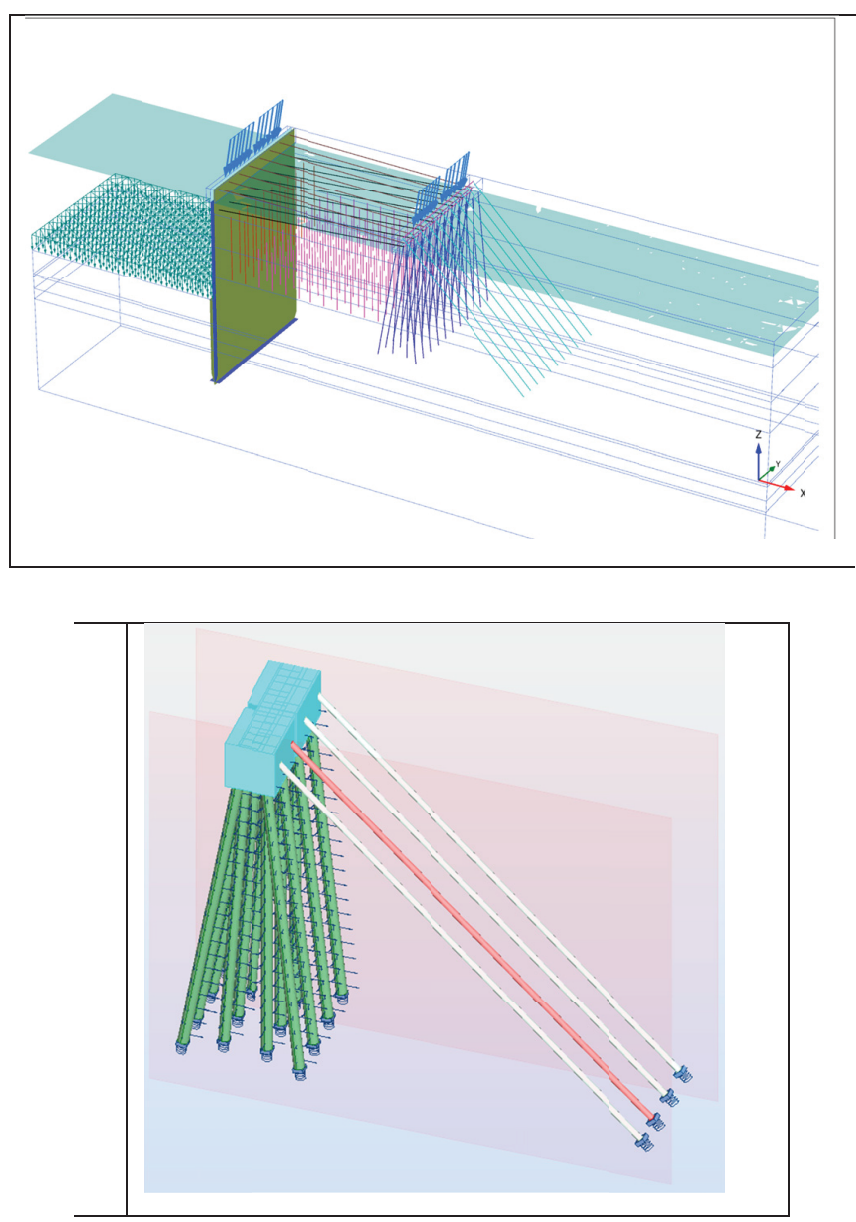

Fig. 4. Schematic diagrams used for calculation of FEM models

For description of the piles, beam elements of elastic boundary conditions and characteristics reproducing interference with the soil medium over pile side surface and in the bottom, were used. The micro-piles, in view of the unique structure of hinged connection between micro-pile and land-side girder (Fig. 5), were defined by means of string elements capable of transferring tension force only.

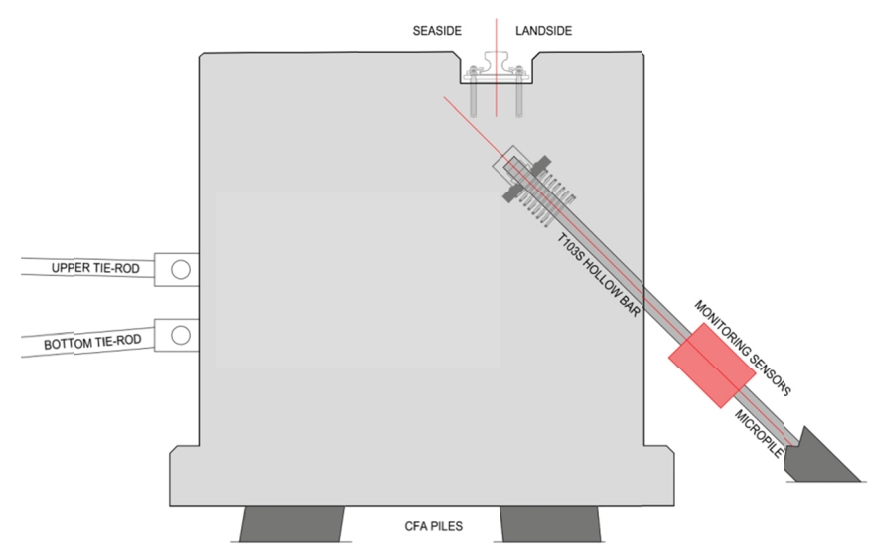

Fig. 5. Detail of hinged connection between micro-pile rod and land-side girder

The performed computational simulations of behaviour of the most unfavourable sections of the land-side girder showed uniform work of the designed rods and the expected force value in ultimate limit state (ULS), with taking into account design values in load cases, had to amount about $1750 \div 1950 \mathrm{kN}$, compared with the design value of loadcarrying ability of the rod - on the level of $2670 \mathrm{kN}$.

To verify correctness of work of selected micro-piles on their completion, load tests were performed (Fig. 6) with the use of mechanical devices [9], [10], [11], [16].

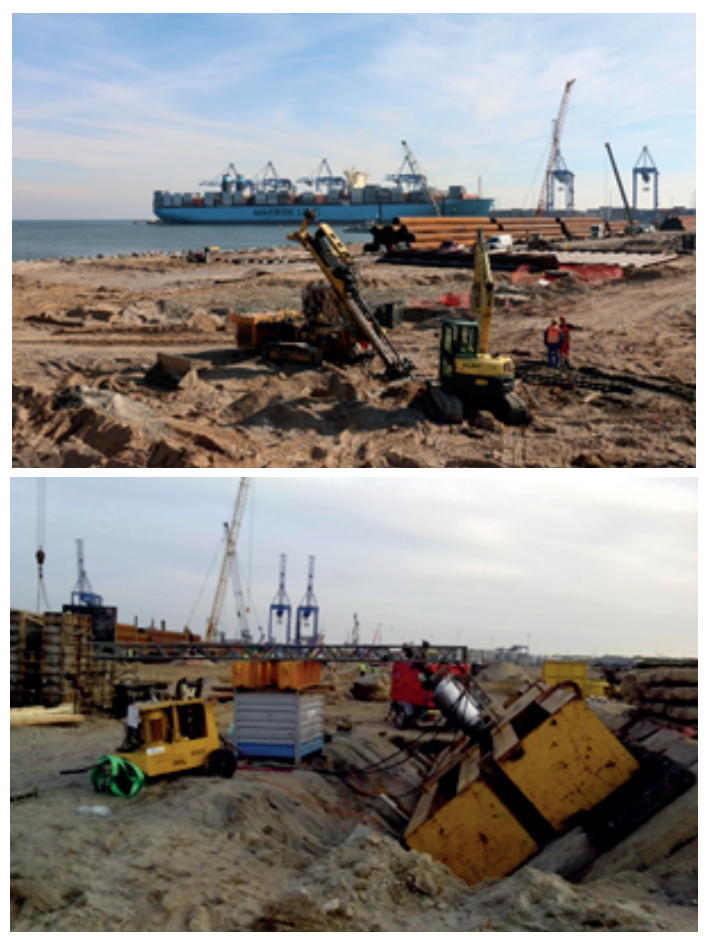

Fig. 6. Production of micro-piles (upper photo), load tests (bottom photo) 


\section{MONITORING SYSTEM}

In the technical monitoring systems for structures [12], [15], [18], [19] it is possible to apply various measuring technologies such as precise levelling, hydrostatic levelling, [2], [21], laser scanning [1], photogrammetric methods [24], advanced geodesic methods as well as specialty measurements of deformations, pressures, temperatures [23] etc, or also numerical simulation modules such as in [17], [22]. The technical monitoring system for micro-piles required to use technologies which make it possible to fulfill the task at relatively low costs. Therefore, for the purposes of the designed system, an innovative system for monitoring axial forces in micro-pile rods, based on measurement of deformations, was produced. To this end, 7 modules of $80 \mathrm{~cm}$ in length was built. Each of them was equipped with dedicated string extensometers. Their calibration was conducted in laboratory conditions with the use of a strength testing machine (Fig. 7). The final product was fitted with a cover and protection system to make operation of the measurement module possible in conditions of elevated pressure resulting from presence of water as well as other actions coming from the soil. The complete measurement modules were tested again in the strength testing laboratory, and their calibration constants - determined.
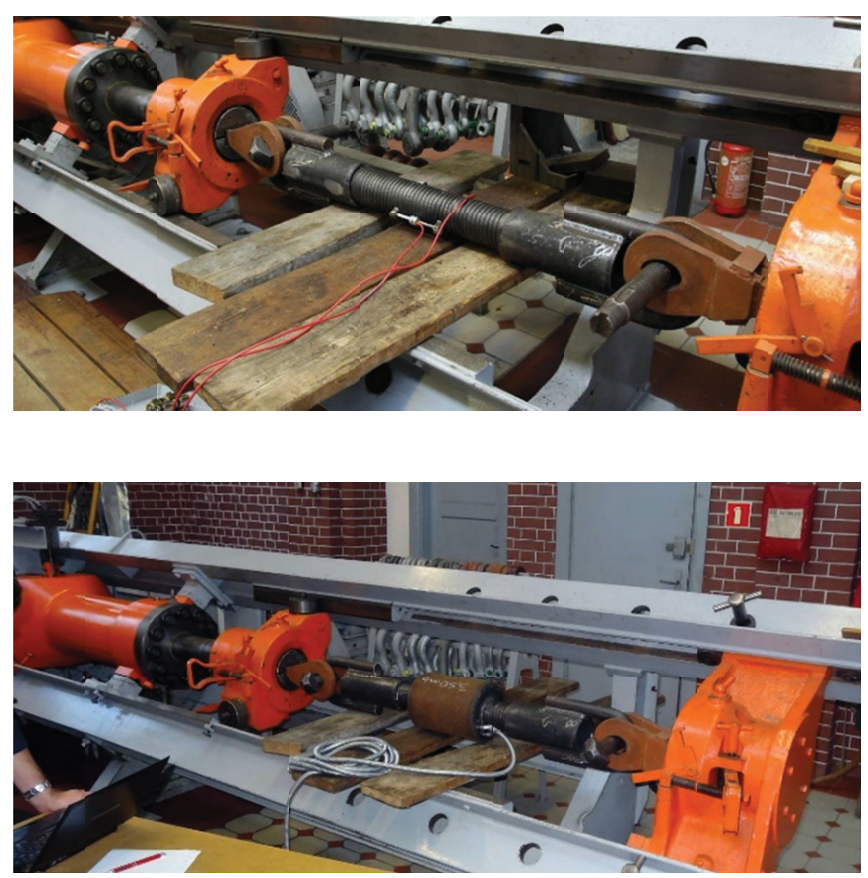

Fig. 7. Tests of the measurement module in the strength testing machine

Measurement of deformations (strains) was carried out with the use of the string extensometers of characteristics given in Tab. 1. The applied gauges are characteristic of a high stability of measurements along the time, and make it possible to measure temperature too.
Tab. 1. Characteristics of the applied measurement gauges

\begin{tabular}{|c|c|}
\hline Measurement range & $3000 \mu \varepsilon$ \\
\hline Resolution & $0,1 \mu \varepsilon$ \\
\hline Accuracy & $\pm 0.5 \%$ F.S. \\
\hline Nonlinearity & $<0.5 \%$ F.S. \\
\hline Temperature range & $-20^{\circ} \mathrm{C} \div 80^{\circ} \mathrm{C}$ \\
\hline
\end{tabular}

Calibration of the string extensometers installed on the rods, concerning identification of force-strain relationship, was of fundamental importance for the preparing of the innovative measurement technology and the ensuring of high quality of measurements. The obtained calibration coefficients made it possible to convert the measured values of rod deformations into values of forces acting in them. In order to increase measurement accuracy 2 gauges were installed on each segment of the rod, then readouts from them were averaged and on this basis a real value of force acting in the rod under axial tension was estimated. The experimental tests were performed in the range $0 \div 400 \mathrm{kN}$, and their example results for the rod $\mathrm{Z} 1$ and $\mathrm{Z} 7$ are presented in Fig. 8. The recorded differences in work of particular gauges on the same segment of the rod were caused by eccentricity of tension occurring in the tests.
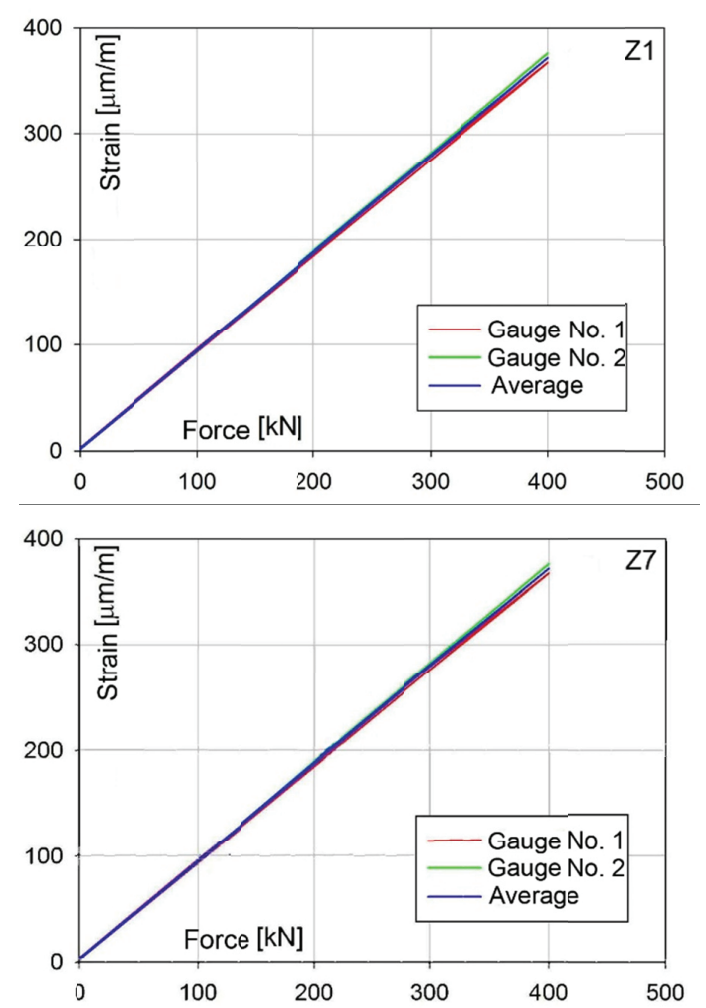

Fig. 8. Characteristics of work of the gauges installed on the rods Z1 and Z7

The tested measurement modules were attached by means of couplers to the micro-piles prepared in advance, and 
then joined with the zinc-coated heads (Fig. 9). Next, before commencement to covering the rods with the soil, each of them was protected against corrosion. Installation of the measurement modules was conducted stage by stage along with progressing the building work. The monitoring of a given rod was started up in the moment of fitting it with gauges at site of the building work ("zeroing measurement").

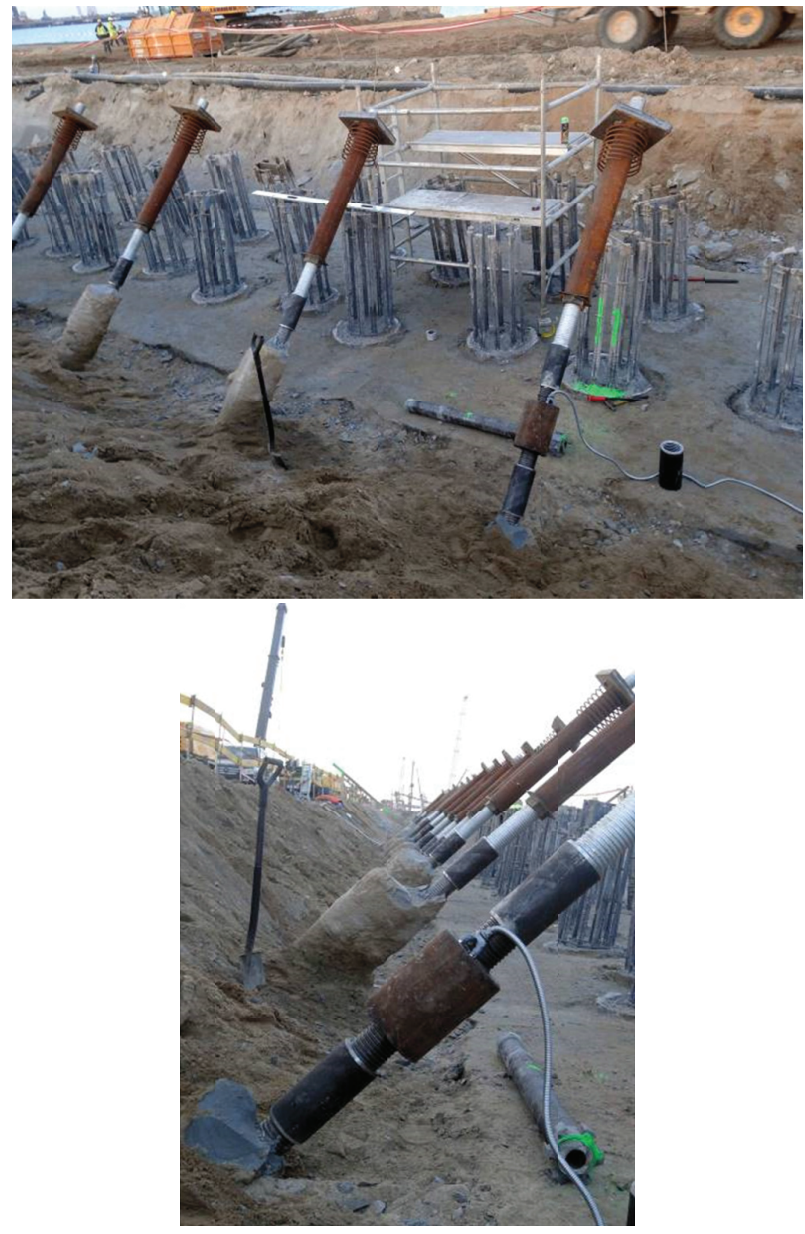

Fig. 9. Installation of the rod Z2 segment fitted with gauges

\section{MONITORING RESULTS}

Taking the readouts from the installed gauges was commenced on 11.02.2016 and beginning from the moment, the operation of the strains monitoring gauges in the rods (in order to then determine forces acting in them) was stable. During taking the readouts were revealed no disturbances or effects which would indicate incorrect work of any of installed extensometers. The only unexpected effect identified during the readouts taking was occurrence - in some building phases of the quay - of a small bending deformation of the rods instead of the expected pure axial tension. The phenomenon was caused by the settling of the quay along with the increasing number of surface courses and it ceased on completion of the building work. Beginning from the instant an increase of tension force acting in each of the rods was only recorded.
The achieved results of the measurements of force in the monitored rods are presented in Fig.10.

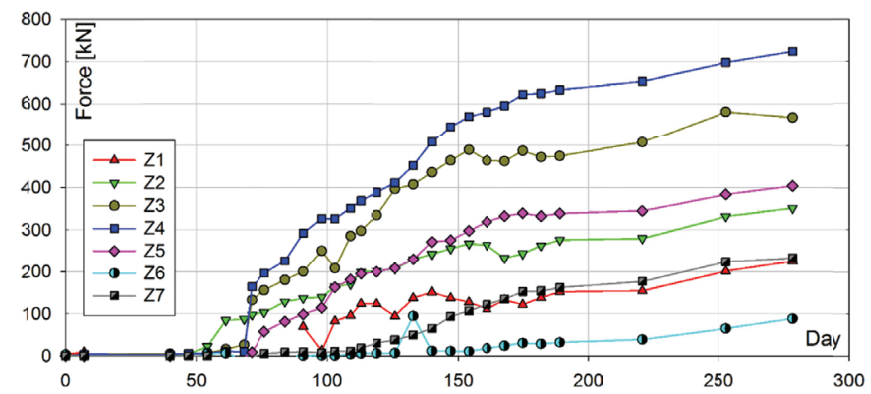

Fig. 10. Changes of forces in the rods

On the basis of the recorded measurements it may be concluded that work of particular rods is not uniform along the quay length $(656 \mathrm{~m})$. The most strained are the rods in the middle of the beam, namely Z3 and Z4, whereas the lowest load were transferred into the extreme elements, i.e. Z1, Z6, $\mathrm{Z7}$. In the rods Z2 and Z5 average force values were observed.

In the case of the rods $\mathrm{Z} 6$ and $\mathrm{Z7}$, a lack of activation of the micro-piles in the initial phase of the monitoring could be caused by a greater stiffness of the piles system in the regions in question, compared with that of the remaining part of the land-side girder. The longest CFA piles placed there took a significant part of load from the quay structure. An influence on the measurements could have the schedule of dredging (deepening) the basin and installing the tie-rods which have not yet started to fully work. During taking the readouts it could be observed that in the zone of the rods $\mathrm{Z} 6$ and $\mathrm{Z7}$ a part of dredging work was continued in the basin just in the time of installing the upper tie-rods, that could result in the transferring horizontal forces in micro-piles of smaller values than expected in this building stage.

In the case of $\mathrm{Z} 1$ rod placed in the connection with the existing terminal T1, a small increase in the measured parameters may be explained by that it was not necessary to deepen the basin in this area and postponed installation of upper tie-rods that made micro-piles to cooperate in full with the quay.

\section{SUMMARY}

The application of the innovative technical monitoring system which makes it possible to monitor forces in the rods, the made-in-advance analysis of design assumptions and calculations for the particular work phases of the quay structure and land-side girder, allowed to show real way of operation of the micro-piles. The most loaded rod, Z4, showed the measured force equal to $724 \mathrm{kN}\left(\mathrm{F}_{\text {meas }}\right)$, whereas its calculated force $\left(\mathrm{F}_{\text {calc }}\right)$ in the representative cross-section and the corresponding current work phase of the element, was equal to $807 \mathrm{kN}\left(\mathrm{F}_{\text {meas }} / \mathrm{F}_{\text {calc }}=90 \%\right)$. Therefore, the monitoring 


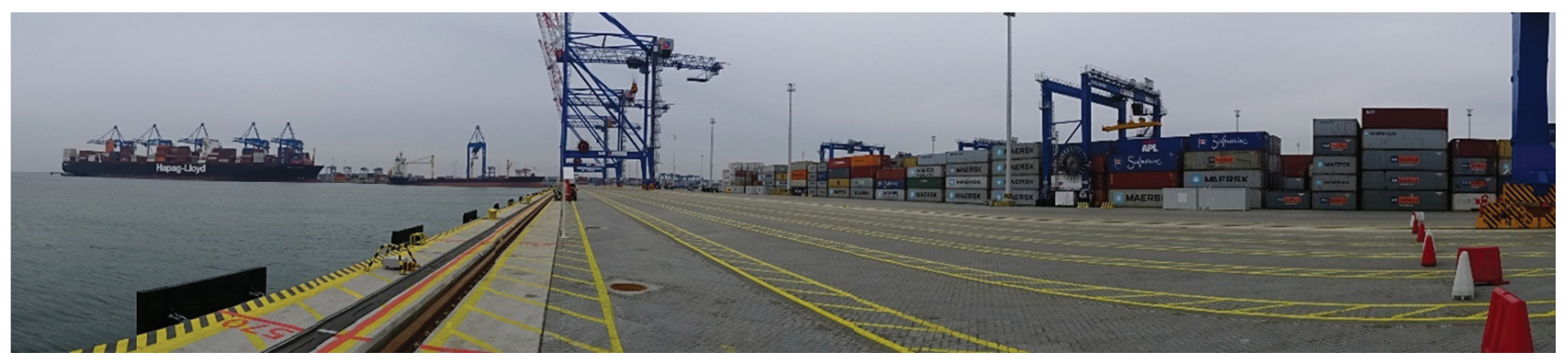

Fig. 12. State of the monitored quay in November 2016

results confirmed that the design assumptions concerning the investigated elements are correct.

Presently, in view of the complex character of the quay structure and the conducting of the building work phase by phase, the measurements are still continued (Fig. 12) in order to observe an influence of the loading generated by weight and operation of cranes, mooring the ships, changes in weather conditions, waving, changes in ground water level etc, on the land-side girder and micro-piles.

\section{BIBLIOGRAPHY}

1. Bernat, M., Janowski, A., Rzepa, S., Sobieraj, A., Szulwic, J.: Studies on the use of terrestrial laser scanning in the maintenance of buildings belonging to the cultural heritage. $14^{\text {th }}$ Geoconference on Informatics, Geoinformatics and Remote Sensing, SGEM. ORG, Albena, Bulgaria, 2014, 3, pp. $307 \div 318$.

2. Boerez J., Hinderer J., Rivera L., Jones M. : Analysis and modeling of the effect of tides on the hydrostatic leveling system at CERN. Survey Review, Maney Publishing, 2012, 44 (327), pp. $256 \div 264$.

3. Buca R., Mitrosz O. : Complex geotechnical engineering for Port of Gdansk development - gateway to Central-Eastern Europe. Proceedings of 13th Baltic Sea Geotechnical Conference. Lithuania, 22 $\div 24$ September 2016 .

4. Burzyński S., Chróścielewski J., Witkowski W.: Geometrically nonlinear FEM analysis of 6-parameter resultant shell theory based on 2-D Cosserat constitutive model. ZAMM-Zeitschrift fur Angewandte Mathematik und Mechanik, Vol. 96, No. 2 (2015), pp.191 $\div 204$

5. Chróścielewski J., Sabik A., Sobczyk B., Witkowski W. : Nonlinear FEM 2D failure onset prediction of composite shells based on 6-parameter shell theory. Thin-Walled Structures 105, (2016), pp. $207 \div 219$.

6. Grelowska G., Kozaczka E., Kozaczka S. : Underwater noise generated by a small ship in the shallow sea. Archives of Acoustics. Vol. 38, (2013), No. 3 pp. 351 $\div 356$.
7. Grelowska G., Kozaczka E.: Underwater Acoustic Imaging of the Sea. Archives of Acoustics.Vol. 39, (2014), No. 4, pp. $439 \div 452$.

8. Janowski A., Nowak A., Przyborski M., Szulwic J. : Mobile indicators in GIS and GPS positioning accuracy in cities. 2nd International Conference on Rough Sets and Emerging Intelligent Systems Paradigms (RSEISP) held as part of Joint Rough Set Symposium (JRS), 2014, Springer International Publishing.

9. Kaliński K.: The finite element method application to linear closed loop steady system vibration analysis. International Journal of Mechanical Sciences 39, 3 (1997), pp. 315 $\div 330$.

10. Kaliński K. J., Galewski M. A.: Chatter vibration surveillance by the optimal-linear spindle speed control. Mechanical Systems and Signal Processing, Vol. 25, No.

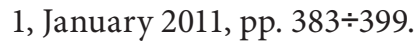

11. Kaliński K. J., Mazur M.: Optimal control at energy performance index of the mobile robots following dynamically created trajectories. Mechatronics 37 (2016), pp. $79 \div 88$.

12. Kaminski W., Makowska K., Miśkiewicz M., Szulwic J., Wilde K. : System of monitoring of the Forest Opera in Sopot structure and roofing, 15th International Multidisciplinary Scientific GeoConference SGEM 2015, SGEM2015 Conference Proceedings, June 18-24, 2015, Book 2, Vol. 2, 2015, pp. $471 \div 482$.

13. Kozaczka E., Grelowska G., Kozaczka S.: Detection of Objects Buried in the Sea Bottom with the Use of Parametric Echosounder. Archives of Acoustics. -Vol. 38, (2013), No. 1, pp. $99 \div 104$.

14. Krupka J., Ryszewska R. : The building of a new quay in the area of Port of Gdansk, to serve for extension of the Gdańsk Deepwater Container Terminal (in Polish), Inżynieria Morska I Geotechnika, No. 1/2016, pp. $38 \div 45$

15. Mariak A., Miśkiewicz M, Meronk B., Pyrzowski Ł. and Wilde K.: Reference FEM model for SHM system of cable-stayed bridge in Rzeszów. Advances in Mechanics: 
Theoretical, Computational and Interdisciplinary Issues - Kleiber et al. (Eds), Taylor \& Francis Group, London, 2016, pp. $383 \div 387$.

16. Mikielewicz J., Mikielewicz D. : A simple model of circular hydraulic pump. International Journal of Heat and Mass Transfer, Vol. 52(1), 2008, pp.17 $\div 21$.

17. Miśkiewicz M. : Nonlinear FEM analysis and monitoring the tie-rod structures (in Polish). Wydawnictwo Politechniki Gdańskiej (Publishing House of Gdańsk University of Technology), 2016.

18. Miśkiewicz M., Pyrzowski Ł., Chróścielewski J., Wilde K.: Structural Health Monitoring of Composite Shell Footbridge for Its Design Validation. Proceedings of 2016 Baltic Geodetic Congress (Geomatics), ed. Juan E. Guerrero Los Alamitos: IEEE Computer Society Order Number E5972, 2016, pp. $228 \div 233$.

19. Rucka M., Wilde K.: Experimental study on ultrasonic monitoring of splitting failure in reinforced concrete. Journal of Nondestructive Evaluation. Vol. 32, (2013), No. 4, pp. $372 \div 383$.

20. Szłapczyński R.: Evolutionary Sets Of Safe Ship Trajectories: A New Approach To Collision Avoidance. Journal of Navigation. Vol. 64, (2011), No. 1, pp.169 $\div 181$.

21. Wilde, K., Meronk B., Groth M., Miśkiewicz, M.: Structure monitoring by means of hydrostatic levelling (in Polish). 27th Scientific Technical Conference on Building failures, 2015 , pp. $278 \div 284$.

22. Wilde, K., Miśkiewicz, M., Chróścielewski, J.: SHM System of the Roof Structure of Sports Arena „Olivia”. Structural Health Monitoring 2013.. Vol. II/ ed. Fu-Kuo Chang, Alfredo Guemes Lancaster, Pennsylvania 17602 U. S. A.:

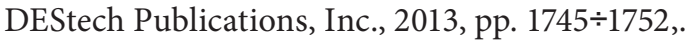

23. Wójcik M., Härtl J., Ooi J.Y., Rotter J.M., Ding S., Enstad G.G.: Experimental investigation of flow pattern and wall pressure distribution in a silo with double-cone insert. Particle\&Particle System Characterization 24, 4-5, 2007, pp. $296 \div 303$

24. Ziolkowski P., Nagrodzka-Godycka K., Janowski A. and Szulwic J.: Remote sensing and photogrammetry techniques in diagnostics of concrete structures. Computers and Concrete, Vol. 18, No. 3, 2016, pp. 405 $\div 420$.

\section{CONTACT WITH THE AUTHOR}

\author{
Mikołaj Miśkiewicz \\ Łukasz Pyrzowski \\ Krzysztof Wilde \\ Gdańsk University of Technology \\ Civil Engineering and Environment Faculty \\ 11/12 Narutowicza St. \\ 80 - 233 Gdańsk \\ Oskar Mitrosz \\ Keller Polska Sp. z o.o. (Co. Ltd) \\ Poland
}

